\title{
Ecological Diversity of Soil Fauna as Ecosystem Engineers in Small-Holder Cocoa Plantation in South Konawe
}

\author{
Laode Muhammad Harjoni Kilowasid ${ }^{1 *}$, Tati Suryati Syamsudin², Franciscus Xaverius Susilo ${ }^{3}$ \\ and Endah Sulistyawati ${ }^{2}$ \\ ${ }^{1}$ Department of Agrotechnology, Faculty of Agriculture, Haluoleo University, Kendari 93232, Indonesia, \\ ${ }^{2}$ School of Life Science and Technology, Institut Teknologi Bandung, Bandung, West Java, Indonesia, \\ ${ }^{3}$ Department of Agrotechnology, Faculty of Agriculture, Lampung University, Bandar Lampung, Indonesia \\ *Corresponding author. lohardjoni2@yahoo.co.id Telp./Fax.: 0401-391692
}

Received 31 March 2012 / accepted 9 May 2012

\begin{abstract}
Taxa diversity within soil fauna functional groups can affected ecosystem functioning such as ecosystem engineers, which influence decomposition and nutrient cycling. The objective of this study is to describe ecological diversity variation within soil fauna as ecosystem engineers in soil ecosystem of cocoa (Theobroma cacao L.) plantation. Sampling was conducted during one year period from five different ages of plantation. Soil fauna removed from soil core using hand sorting methods. A total of 39 genera of soil fauna as ecosystem engineers were found during these studies. Thirty five genera belong to the group of Formicidae (ants), three genera of Isoptera (termites), and one genera of Oligochaeta (earthworms). Ecological diversity variation within ecosystem engineers was detected with Simpson indices for dominance and evenness. The highest diversity of ecosystem engineers was in the young age of plantation. This study reinforces the importance biotic interaction which contributed to the distribution and abundance within soil fauna community as ecosystem engineers in small-holder cocoa plantation.
\end{abstract}

Keywords: Cocoa, diversity, ecosystem engineers, small-holder, soil fauna

\section{INTRODUCTION}

In terrestrial ecosystem, explanation impact of human activity on biodiversity mostly dominated by the studies from aboveground communities (Hooper et al. 2005). Currently, the new approach proposed by Parker (2010) that biodiversity should not considered only on the number of species but also functional groups of the species in the community. In fact, belowground ecosystem and functional group of species was neglected, because of the absence of direct economical values (Decaens 2006) and 'charismatic' species of soil fauna (Susilo et al. 2004).

The soil fauna has an indirect effect on economical values through their functional groups activity such as ecosystem engineers (Decaens et al. 2006). Some experimental studies showed that soil fauna diversity strongly related to decomposition and nutrient cycling through their functional groups activities as detritivorous, omnivorous, predator, or ecosystem engineers (Swift et al. 2004). The soil fauna including ants, earthworms, and termites are

J Trop Soils, Vol. 17, No. 2, 2012: 173-180

ISSN 0852-257X categorized as ecosystem engineers by its connection with their role to modify soil properties, and provide an available substrate for microbial (Jones et al. 1994). Some studies used soil fauna as ecosystem engineers for ecosystem restoration (Butt et al. 1995; Butt 1999; Byers et al. 2006). Earlier researchers in tropical environment were reported that earthworm, termites, or ant species had different effect on soil properties (structure and aggregate) e.g. Blanchart et al. (1997); Decaëns et al. (2002); and Hedde et al. (2005). Further, Barois and Lavele (1986) found a mutualistic relationship between micro flora and earthworms (Pontoscolex corethrurus) of exploitation organic complex in the tropical soil. Straube et al. (2009) reported that the presence of Dendrobaena octaedra and Octolasion tyrtaeum had different impact on density and diversity of soil micro arthropod, and Dauber et al. (2008) reported that the presence of ant stimulated increasing arbuscular mycorrhizal fungi (AMF) density in grasses roots around. The change within soil fauna community (as ecosystem engineers) could be influenced on soil structure, and activity of soil microbe and micro-arthropod, which will regulate on nutrient cycling in the soil (Osler and Sommerkorn 2007). Consequently it will affect plant productivity including fruit, grain, flower, fiber, 
medicinal plant, oil, etc (Benckiser and Schnell 2007). These facts indicate the importance of soil fauna diversity as ecosystem engineers in regulation and maintenance of stability of soil biota community, including as an indicator of soil quality and soil biological classification.

In Indonesia, cocoa plantations cover about 1.75 millions ha, and 1.64 millions ha are belong to smallholder farm (Directorate General of Estate, Agricultural Ministry, Republic of Indonesia 2011) and most of the studies on belowground soil fauna in cocoa plantation (cocoa agroforestry) focus on its importance on conserving biodiversity (Delabie et al. 2007; Moco et al. 2009; Shahabuddin 2010). The study on the important of the behavior of soil fauna as functional group in different age of cocoa plantation is neglected. The objective of this study was to describe ecological diversity variation within soil fauna as ecosystem engineers in the small holder cocoa plantation. Pricesely, (i) to find out soil fauna diversity as ecosystem engineers in different age of cocoa plantation; (ii) to find out the ecological diversity measurements for different habitat (age of cocoa plantation); and (ii) to find out the diversity status of ecosystem engineers in different habitat.

\section{MATERIALS AND METHODS}

\section{Study Site}

This study was conducted in smallholder farmer cocoa (Theobroma cacao L.) plantation which was extensively managed at Konda and Mowila sub- districts in South Konawe District, South East Sulawesi, which were located at $040^{\circ} 7^{\prime} 04.9^{\prime \prime}-040^{\circ} 8^{\prime} 50.5^{\prime}$ "South latitude and $122^{\circ} 15^{\prime} 02.8^{\prime \prime}-122^{\circ} 31^{\prime} 40.5$ " East longitude. The rainfall average of the area study was $175.58 \mathrm{~mm} \mathrm{month}^{-1}$, and air temperature was $26.74^{\circ} \mathrm{C}$, this data was obtained from weather station of Wolter Monginsidi Port Kendari. The topography of the area was with slope of $0-3 \%$. Soil type in the area studies were included in Dystrudepts Typical sub-group (Soil Survey Staff 2010).

\section{Samples Collection and Experimental Designs}

Determination of study site was conducted on April 2009 by surveying different age of small holder cocoa plantation and it was decided to work on five different ages of plantation, that were 4, 5, 7, 10, and 16 age-years (Figure 1). In each site (different age of plantation), samples were taken from the area of 0.25 ha $(50 \mathrm{~m} \times 50 \mathrm{~m})$. In each area it were taken four soil corers with distance between one soil core and others were away of $10 \mathrm{~m}$ following the experimental design at Figure 2. Soil fauna was collected by soil cores by cylindrical stainless steel core with $20 \mathrm{~cm}$ in diametre and $15 \mathrm{~cm}$ in soil depth. Samples were collected at five times during one year period at 15 August 2009, 21 November 2009, 26 January 2010, 22 April 2010, and 13 June 2010.

The soil fauna was removed from soil core using hand sorting methods and preserved in 70\% alcohol. Identification was conducted following identification guide from Hashimoto (2010) for ants, James (2000) for earthworms, and Tho (1992) for termites. Due to the limitation of key to species level, identification

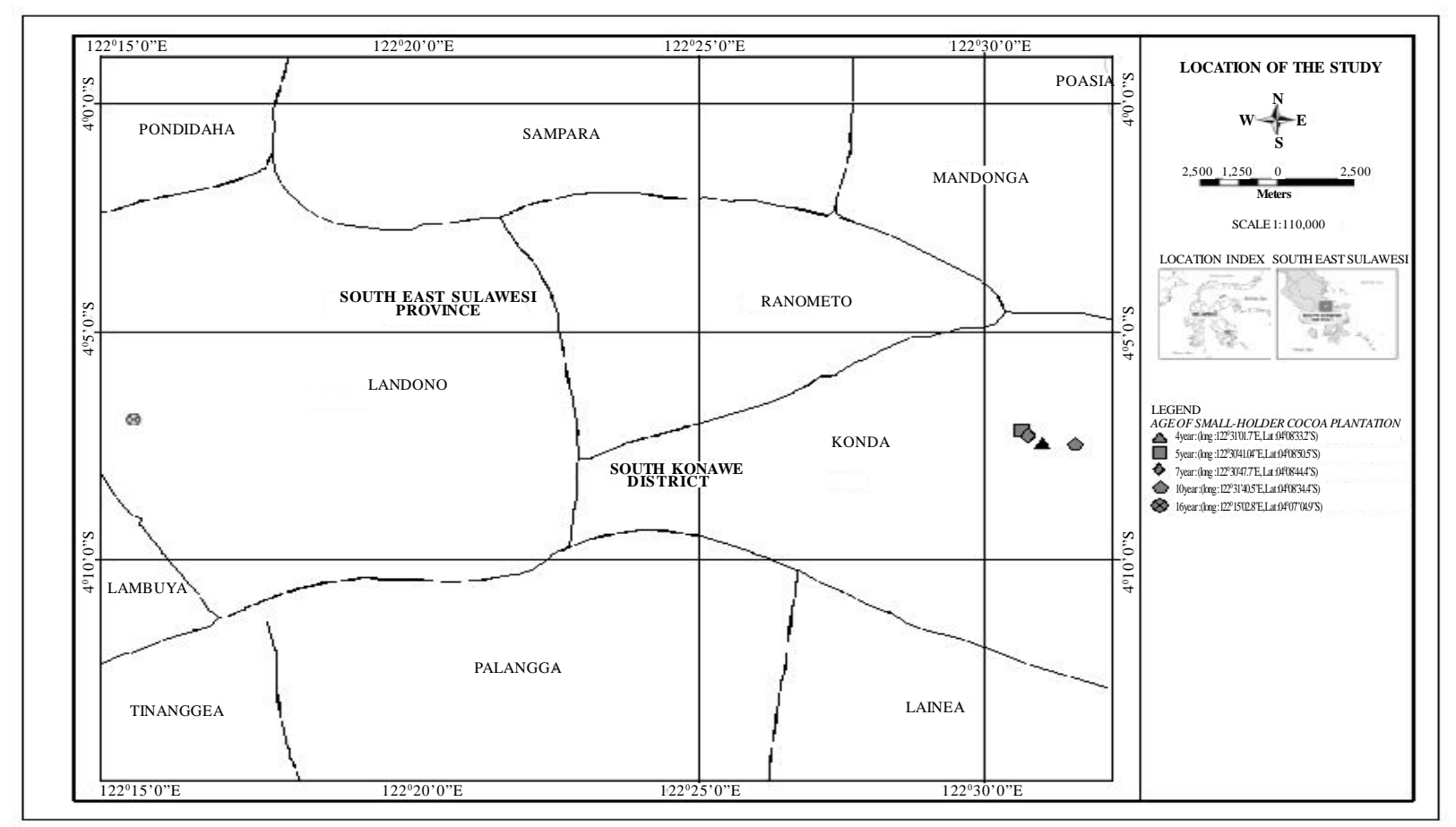

Figure 1. Sampling site of the research. 


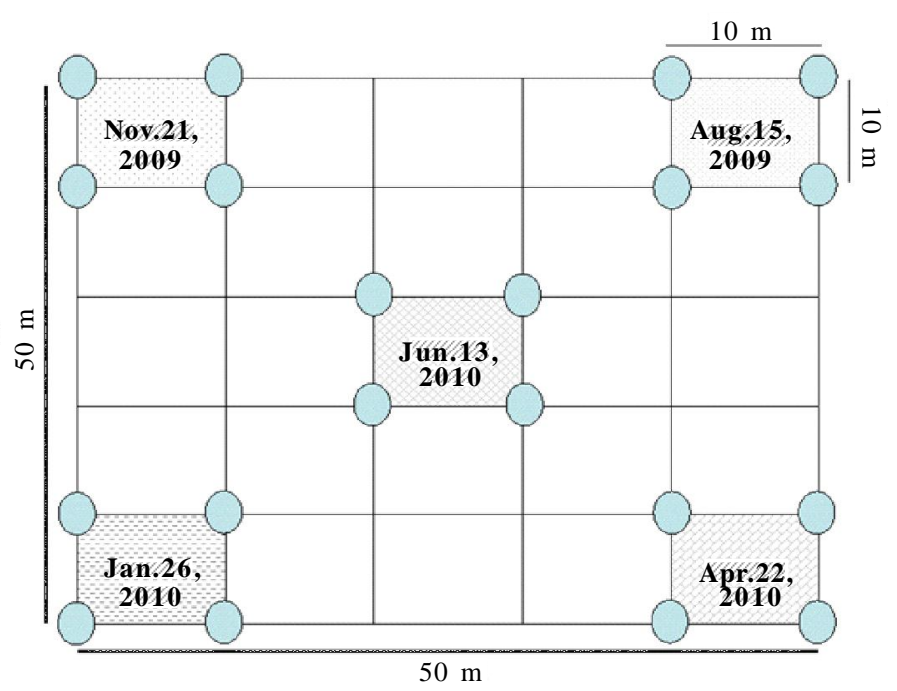

Figure 2. Experimental designs for soil fauna sampling. Notes: $\bigcirc$ sampling point.

was done up to genera and it was also used for analysis of richness, dominance, and evenness. The data of each genera was transformed into number per square metre.

\section{Measures of Ecological Diversity and Statistical Analysis}

To measure ecological diversity were used genera richness, and the indices from Shannon, Simpson, and Camargo for dominance, evenness, diversity, and uniformity. Every of indices were calculated using the formula of Camargo (2008). Univariate analysis of variance was used to detect variations in the value of the indices of ecological diversity among different age of cocoa plantation. Comparison of each value of measures of ecological diversity among different age of the cacao plantation was conducted with the Duncan test at the $\mathrm{p}<0.05$ level.

\section{RESULTS AND DISCUSSION}

\section{Genera Richness of Soil Fauna as Ecosystem Engineers}

During one year period of the research, a total of 828 individual consisting of 39 genera of soil fauna as ecosystem engineers was collected from the different age of cocoa plantation. Three groups of soil fauna which were categorized as ecosystem engineers were ants, termites, and earthworms. From the total of genera of soil fauna were 35 of genera belong to Formicidae (ants), three genera of Isoptera (termites), and one genera of Oligochaeta (earthworms). The highest richness was 22 genera found in plantation aged 4 years and the lowest was 12 genera found in plantation aged 5 years (Table 1). In Table 2 it shows ants from the genera of Solenopsis, Harpegnathos, Platythyrea, and Proceratium, and earthworm from the genera of Pontoscolex found at all age of plantation. Ants from genera of Neivamyrmex, Euprenolepis, Crematogaster, Olygomyrmex, Brachyponera, Cryptopone, and Mesoponera were found at the younger age of plantation (between 4-5years age). Leptothorax, Oecophylla, Atta, and Ponera were found at the midle age of plantation (7 years), and Amblypone, Camponatus, Ephebomyrmex, Liometoprum, Pseudolasius and Veromesor were found at the old plantation (10-16 years old). For termites, genera of Coptotermes and Pericapritermes were found in the plantation aged of 4,10 , and 16 years, while the Hypotermes was

Table 1. Number of genera of the soil fauna as ecosystem engineers from different age of small-holder cocoa plantation.

\begin{tabular}{lccccc}
\hline Taxa & 4 year & 5 year & 7 year & 10 year & 16 year \\
\hline Ants & 19 & 11 & 13 & 16 & 13 \\
Termites & 2 & - & 1 & 2 & 3 \\
Earthworms & 1 & 1 & 1 & 1 & 1 \\
\hline Total & 22 & 12 & 15 & 19 & 17 \\
\hline
\end{tabular}

Age class: 4 and 5 year $=$ young plantation, 7 year $=$ middle plantation, and 10 and 16 year $=$ old plantation. 
only found in the oldest of the plantation (16 year). For earthworms, only Pontoscolex was found in all age of the plantations.

The results showed that the richness of the ant genera was higher than termites and earthworms.
These phenomena are very commonly observed in the plantation areas in tropical regions (Moco et al. 2009; Turner and Foster 2009). The dominance of ants in the soil macro-fauna community were caused by a number of functional properties of them,

Table 2. Ants, termites, and earthworms collected from different age of small-holder cocoa plantation.

\begin{tabular}{|c|c|c|c|c|c|}
\hline \multirow{2}{*}{ Genera } & \multicolumn{5}{|c|}{ Age of cocoa plantation (years) } \\
\hline & 4 & 5 & 7 & 10 & 16 \\
\hline \multicolumn{6}{|l|}{ Ants } \\
\hline Liometoprum & - & - & - & 1 & - \\
\hline Tapinoma & 1 & 1 & - & 1 & - \\
\hline Neivamyrmex & 1 & - & - & - & - \\
\hline Camponatus & - & - & - & 1 & - \\
\hline Euprenolepis & 1 & 1 & - & - & - \\
\hline Oecophylla & - & - & 1 & - & - \\
\hline Pseudolasius & - & - & - & - & 1 \\
\hline Cardiocondela & 1 & - & - & 1 & - \\
\hline Crematogaster & 1 & - & - & - & - \\
\hline Ephebomyrmex & - & - & - & 1 & - \\
\hline Leptothorax & - & - & 1 & - & - \\
\hline Monomorium & - & - & 1 & 1 & - \\
\hline Olygomyrmex & - & 1 & - & - & - \\
\hline Pheidole & 1 & - & 1 & - & 1 \\
\hline Pogonomyrmex & 1 & - & - & 1 & - \\
\hline Prystomyrmex & 1 & 1 & - & - & 1 \\
\hline Solenopsis & 1 & 1 & 1 & 1 & 1 \\
\hline Tetramorium & 1 & - & - & 1 & - \\
\hline Veromesor & - & - & - & - & 1 \\
\hline Amblypone & - & - & - & 1 & - \\
\hline Atta & - & - & 1 & - & - \\
\hline Brachyponera & 1 & - & - & - & - \\
\hline Centromyrmex & 1 & - & 1 & 1 & 1 \\
\hline Cryptopone & 1 & - & - & - & - \\
\hline Discothyrea & - & 1 & - & - & 1 \\
\hline Emyryopone & 1 & 1 & - & - & 1 \\
\hline Hypoponera & 1 & - & 1 & 1 & - \\
\hline Mesoponera & 1 & - & - & - & - \\
\hline Harpegnathos & 1 & 1 & 1 & 1 & 1 \\
\hline Pachycondyla & - & 1 & - & - & 1 \\
\hline Platythyrea & 1 & 1 & 1 & 1 & 1 \\
\hline Ponera & - & - & 1 & - & - \\
\hline Prionopelta & - & - & - & - & 1 \\
\hline Proceratium & 1 & 1 & 1 & 1 & 1 \\
\hline Pseudomyrmex & - & - & 1 & 1 & - \\
\hline \multicolumn{6}{|l|}{ Termites } \\
\hline Coptotermes & 1 & - & 1 & 1 & 1 \\
\hline Hypotermes & - & - & - & - & 1 \\
\hline Pericapritermes & 1 & - & - & 1 & 1 \\
\hline \multicolumn{6}{|l|}{ Earthworms } \\
\hline Pontoscolex & 1 & 1 & 1 & 1 & 1 \\
\hline
\end{tabular}

Notes: (-) absent, (1) present. 
namely high mobility and high ability to colonize in a habitats (Campos et al. 2007; Delabie et al. 2007), some ant species can change their diet at the time of the poor availability of basic food resource (Tillberg et al. 2007), and variations in morphology and size that supports the success to colonize on various microhabitat (Silva and Brandao 2010). Wielgoss et al. (2010) also found that ant abundance responded on temperature change in cocoa plantation. Low richness of the genera of termites in the soil of cocoa agroforestry was also reported by Moco et al. (2009), and it was also occurred in the area of the other plantation (Gillison et al. 2003; Aeckerman et al. 2009). Activities of farmers in the most plantation area (including cocoa plantation) led to soil compaction, resulting bulk density of the soil increased (Hairiah et al. 2006), consequent it negatively affected the species (genera) richness of termites (Gillison et al. 2003; Jones et al. 2003; Miranda et al. 2004; Norgrove et al. 2009; Moco et al. 2010). Pontoscolex was very dominant in the area of plantations in the tropical region (Nunes et al. 2006; Sabrina et al. 2009; Nath and Chaudhury 2010). The dominance of Pontoscolex than the other earthworms groups were believed strongly associated with the adaptive nature of the condition of lower soil pH (Baker et al. 1997; Henrot and Brussard 1997; Nunes et al. 2006; Chaudhuri et al. 2008) in this studies area was in the ranged of 4.37-4.93 (Kilowasid et al. 2010), the ability to compete and to colonize in ground habitats was disturbed (Gonzalez et al. 2006).

\section{Ecological Diversity Variation}

Simpson indices for dominance and evenness among cocoa plantation of the different age were significant $(\mathrm{p}<0.0045)$, whereas differences in other measures of the indices of soil fauna diversity as ecosystem engineers in the different ages of the plantation were not significant (Table 3). This indicated that the Simpson indices for dominance and evenness compare with other measures of the diversity indices was more sensitive to change in the number of genera and distribution of individuals among genera of the soil fauna in line with the increasing of the plantation age (Rosensweigh 1999; Beisel et al. 2003; Mathieu et al. 2005).

Difference of the Simpson indices values for dominance in the communities of soil fauna as ecosystem engineers in cocoa plantations aged 4, 10 , and 16 years compared to Simpson indices values for dominance at cocoa plantation aged 5 year was significant $(\mathrm{p}<0.05)$. Highest value of the Simpson indices for dominance has occurred in the cocoa plantation aged 4 year, while the lowest value has occurred in the plantation aged 5 year. In contrast, Simpson indices for evenness within community of soil fauna as ecosystem engineers in cacao plantation aged 5 years compared to Simpson indices for evenness in cocoa plantation aged 4,10 , and 16 years were significantly different. The highest value of the Simpson indices for evenness has occurred at the cocoa plantations aged 5 year, while the lowest

Table 3. Measures of ecological diversity within soil fauna community as ecosystem engineers in smallholder cocoa plantations with different age.

\begin{tabular}{lccccc}
\hline \multirow{2}{*}{ Ecological diversity indices } & \multicolumn{5}{c}{ Small-holder cocoa plantation age (years) } \\
\cline { 2 - 6 } & $\mathbf{4}$ & $\mathbf{5}$ & $\mathbf{7}$ & $\mathbf{1 0}$ & $\mathbf{1 6}$ \\
\hline Genera dominance: & & & & & \\
Shannon indices & $0.668 \pm 0.050 \mathrm{a}$ & $0.398 \pm 0.075 \mathrm{a}$ & $0.525 \pm 0.028 \mathrm{a}$ & $0.582 \pm 0.101 \mathrm{a}$ & $0.594 \pm 0.068 \mathrm{a}$ \\
Simpson indices & $0.623 \pm 0.057 \mathrm{~b}$ & $0.238 \pm 0.121 \mathrm{a}$ & $0.400 \pm 0.069 \mathrm{ab}$ & $0.544 \pm 0.095 \mathrm{~b}$ & $0.546 \pm 0.074 \mathrm{~b}$ \\
Camargo indices & $0.638 \pm 0.084 \mathrm{a}$ & $0.265 \pm 0.103 \mathrm{a}$ & $0.460 \pm 0.059 \mathrm{a}$ & $0.519 \pm 0.080 \mathrm{a}$ & $0.522 \pm 0.067 \mathrm{a}$ \\
Genera evenness: & & & & & \\
Shannon indices & $0.333 \pm 0.050 \mathrm{a}$ & $0.603 \pm 0.075 \mathrm{a}$ & $0.475 \pm 0.028 \mathrm{a}$ & $0.418 \pm 0.101 \mathrm{a}$ & $0.406 \pm 0.068 \mathrm{a}$ \\
Simpson indices & $0.378 \pm 0.057 \mathrm{a}$ & $0.763 \pm 0.121 \mathrm{~b}$ & $0.600 \pm 0.069 \mathrm{ab}$ & $0.456 \pm 0.095 \mathrm{a}$ & $0.454 \pm 0.074 \mathrm{a}$ \\
Camargo indices & $0.363 \pm 0.084 \mathrm{a}$ & $0.735 \pm 0.103 \mathrm{a}$ & $0.540 \pm 0.059 \mathrm{a}$ & $0.481 \pm 0.080 \mathrm{a}$ & $0.478 \pm 0.067 \mathrm{a}$ \\
Genera diversity: & & & & & \\
Shannon indices & $2.628 \pm 0.687 \mathrm{a}$ & $2.153 \pm 0.400 \mathrm{a}$ & $2.475 \pm 0.414 \mathrm{a}$ & $2.378 \pm 0.418 \mathrm{a}$ & $2.523 \pm 0.581 \mathrm{a}$ \\
Simpson indices & $3.325 \pm 1.364 \mathrm{a}$ & $2.833 \pm 0.732 \mathrm{a}$ & $3.255 \pm 0.839 \mathrm{a}$ & $2.730 \pm 0.649 \mathrm{a}$ & $3.015 \pm 0.950 \mathrm{a}$ \\
Camargo indices & $3.130 \pm 1.344 \mathrm{a}$ & $2.703 \pm 0.652 \mathrm{a}$ & $2.903 \pm 0.754 \mathrm{a}$ & $2.988 \pm 0.702 \mathrm{a}$ & $3.178 \pm 0.950 \mathrm{a}$ \\
Genera uniformity: & & & & & \\
Shannon indices & $0.438 \pm 0.078 \mathrm{a}$ & $0.518 \pm 0.095 \mathrm{a}$ & $0.436 \pm 0.065 \mathrm{a}$ & $0.468 \pm 0.093 \mathrm{a}$ & $0.465 \pm 0.102 \mathrm{a}$ \\
Simpson indices & $0.423 \pm 0.099 \mathrm{a}$ & $0.445 \pm 0.125 \mathrm{a}$ & $0.375 \pm 0.095 \mathrm{a}$ & $0.435 \pm 0.104 \mathrm{a}$ & $0.442 \pm 0.128 \mathrm{a}$ \\
Camargo indices & $0.473 \pm 0.132 \mathrm{a}$ & $0.448 \pm 0.112 \mathrm{a}$ & $0.402 \pm 0.075 \mathrm{a}$ & $0.411 \pm 0.118 \mathrm{a}$ & $0.415 \pm 0.120 \mathrm{a}$ \\
\hline
\end{tabular}

Samples number $=20$, mean \pm SE. Different letter following number in the same row shown significant according to Duncan test at the $\mathrm{p}<0.05$ level. 
Table 4. Status of relative abundance of genera within soil faunal communities as ecosystem engineers in small-holder of cocoa plantation with different age.

\begin{tabular}{lccccc}
\hline Relative abundance status & \multicolumn{5}{c}{ Proportion (\%) of genera status in different age of cocoa plantation } \\
\cline { 2 - 6 } of genera & 4 year age & 5 year age & 7 year age & 10 year age & 16 year age \\
\hline Rare genera & 68.18 & 50.00 & 73.33 & 70.00 & 66.67 \\
Median genera & 22.73 & 41.67 & 26.67 & 30.00 & 33.33 \\
Dominant genera & 9.09 & 8.33 & 0.00 & 0.00 & 0.00 \\
\hline
\end{tabular}

Notes: rare genera is a genera have a relative abundance $<5 \%$, median genera is a genera have a relative abundance between $5 \%-40 \%$ and dominant generais a genera have a relative abundance e" 40\% (Beis et al. 2003; Camargo, 2008).

value of the evenness indices has occurred at the cocoa plantation aged 4 year. Differences in Simpson indices for dominance and evenness in cocoa plantation aged 7 year than Simpson indices for dominance and evenness in cocoa plantation aged $4,5,10$, and 16 years were not significantly $(p>0.05)$. These results mean that changes in the ecological diversity of soil fauna communities as ecosystem engineers were fluctuated with age of the cocoa plantations. Studies elsewhere using chronosequences approach also found the differentiation pattern of ecological diversity of soil fauna communities was not apparent as the age of the plantation (Hanel 2001; Addison et al. 2003). These results reinforced the notion that the ecological diversity of genera in the soil fauna communities as ecosystem engineers were not only controlled by environmental factor, but also by mobility and success of genera colonized every habitat in the soil at the age of the small holder cocoa plantations.

\section{Status of Genera Diversity within Soil Fauna as Ecosystem Engineers}

Table 4 shows that based on the relative abundance of genera, the proportion of rare genera in the soil fauna as ecosystem engineers was higher than the median proportion and dominant genera in all age cocoa plantations. Dominant genus only looked at the young age of the cocoa plantations (4 and 5 years), and the proportion decreased with increasing age of the cocoa plantations. Previous researchers also found that rare taxa were generally dominant in the soil fauna community in cocoa plantations (Aeckermann et al. 2009; Delabie et al. 2007; Moco et al. 2009). The large number of rare genera indicates that the soil fauna communities as ecosystem engineers are highly vulnerable to loss of species or genera members (Diaz and Cabido 2001; Hubbell 2001; Fattorani $e t$ al. 2012). Endangered genera to be the main factor considered to preserve the soil fauna communities as ecosystem engineers (Virolainen et al. 1998; Moco et al. 2009; Norgrove et al. 2009; Mertl et al. 2012). Conservation of rare genera within functional group (ecosystem engineers) to be an important key in maintaining sustainability of ecosystem functioning such as decomposition, nutrient cycling and productivity (Lavelle 1996; Diaz and Cabido 2001; Coleman 2008) from small-holder cocoa plantations.

\section{CONCLUSIONS}

Ecological diversity variation within soil fauna community as ecosystem engineers in the different age of small-holder cocoa plantation showed that species diversity was related to the age of cocoa plantation. Genera richness of soil fauna as ecosystem engineers was highest in the younger cocoa plantation. Ant diversity was dominant in soil fauna community as ecosystem engineers in the cocoa plantation. Genera diversity in old cocoa plantation was higher than in young plantation, this phenomenon was shown by the highest proportion of rare genera. In different age of cocoa plantation, ecological diversity was detected only by Simpson indices for dominance and evenness.

\section{ACKNOWLEDGEMENTS}

We would like to thank the Directorate General of Higher Education, Ministry of National Education Republic of Indonesia for scholarships (BPPS Grant) for the Doctoral Program in the School of Biological Science and Technology ITB and "Competitive Research Grant year 2011" for the first author (Laode Muh Harjoni Kilowasid). Part of this research is also funded by ITB Grant (Hibah Peningkatan Institusi Tahun 2010-2011) to the second author (Tati S Syamsudin) as the staff of the SITH - ITB. Many thanks to everyone who helped us during field work in South Konawe, Southeast Sulawesi. 


\section{REFERENCES}

Addison JA, JA Trofymow and VG Marshall. 2003. Abundance, species diversity, and community structure of Collembola in successional coastal temperate forests on Vancouver Island, Canada. Appl Soil Ecol 24: 233-246.

Aeckerman IL, R Constantio, HG Gauch, J Lehmann, SJ Riha and ECM Fernandes. 2009. Termite (insecta: isoptera) species composition in a primary rain forest and agroforests in Central Amazonia. Biotropica 41 (2): 226-233.

Baker GH, TA Thumlert, LS Meisel, PJ Carter and GP Kilpin. 1997. "Earthworms downunder": A survey of the earthworms fauna of urban and agricultural soil in Australia. Soil Biol Biochem 29: 589-597.

Barois I and P Lavelle. 1986. Changes in respiration rate and some physicochemical properties of a tropical soil during transit through Pontoscolex corethrurus (Glossoscolecidae, Oligochaeta). Soil Biol Biochem 18: 539-541.

Beisel JN, P Usseglio-Polatera, V Bachmann and JC Moreteau. 2003. A comparative analysis of evennes index sensitivity. Inter Rev Hydrobiol 88: 3-15.

Benckiser G and S Schnell. 2007. Biodiversity in agricultural production systems. CRC Press. Boca Raton.

Blanchart E, P Lavelle, E Braudeau, YL Bissonnais and C Valentin. 1997. Regulation of soil structure by geophagous earthworm activities in humid savannas of Côte D'Ivoire. Soil Biol Biochem 29: 431-439.

Butt KR, J Frederickson and RM Morris. 1995. An earthworm cultivation and soil inoculation technique for land restoration. Ecol Eng 4: 1-9.

Butt KR. 1999. Inoculation of earthworms into reclaimed soils: the UK experience. Land Degrad Develop 10: 565-575.

Byers JE, K Cuddington, CG Jones, TS Talley, A Hasting, JG Lambrinos, JA Crooks and WG Wilson. 2006. Using ecosystem engineers to restore ecological systems. Trends Ecol Evol 21: 493-500.

Camargo JA. 2008. Revisiting the relation between species diversity and information theory. Acta Biotheor 56: 275-283.

Campos BFR, JH Schroeder and CF Sperber. 2007. Smallscale patch dynamics after disturbance in litter ant communities. Basic Appl Ecol 8: 36-43.

Caudhuri PS, S Nath and R Paliwal. 2008. Earthworm population of rubber plantations (Hevea brasiliensis) in Tripura, India. Trop Ecol 49 (2): 225-234.

Coleman DC. 2008. From peds to paradoxes: Linkages between soil biota and their influences on ecological processes. Soil Biol Biochem 40: 271289. doi:10.1016/j.soilbio.2007.08.005.

Dauber J, R Niechoj, H Baltruschat and V Wolters. 2008. Soil engineering ants increase grass root arbuscular mycorrhizal colonization. Biol Fertil Soils 44: 791-796.
Decaëns T, N Asakawa, JH Galvis, RJ Thomas and E Amézquita. 2002. Surface activity of soil ecosystem engineers and soil structure in contrasted land use systems of Colombia. Europ J Soil Biol 38: 267271.

Decaëns T, JJ Jiménez, C Gioia, GJ Measey and PLavelle. 2006. The values of soil animals for conservation bilogy. Europ J Soil Biol 42: S23-S38.

Delabie JHC, B Jahyny, IC do Nascimento, CSF Mariano, S Lacau, S Campiolo, SM Philpott and M Leponce. 2007. Contribution of cocoa plantation to the conservation of native ants (Insecta: Hymenoptera: Formicidae) with a special emphasis on the Atlantic Forest Fauna of southern Bahia, Brazil. Biodiver Conserv 16: 2359-2384.

Diaz S and M Cabido. 2001. Vive la difference: plant functional diversity matters to ecosystem processes. Trend Ecol Evol 16(11): 646-655.

Directorate General of Estate, Agricultural Ministry, RI 2011. Area and production by category of producers http://ditjenbun.deptan.go.id/cigraph/index.php/ viewstat/komoditiutama/4-Kakao. Downloaded at: November 25, 2011.

Fattorini S, P Cardoso, F Rigal and PAV Borges. 2012. Use of arthropod rarity for area prioritisation: insights from the Azorean Islands. Plos ONE 7(3): 1-9.

Gillison AN, DT Jones, FX Susilo and DE Bignell. 2003. Vegetation indicates diversity of soil macroinvertebrates: a case study with termites along a land-use intensification gradient in lowland Sumatra. Org Divers Evol 3: 111-126.

Gonzáles G, CY Huang, X Zou and C RodrÉguez. 2006. Earthworm invasions in the tropics. Biol Invasions 8: 1247-1256.

Hairiah K, H Sulityani, D Suprayogo, Widianto, P Purnomosidhi, RH Widodo and M van Noordwijk. 2006. Litter layer residence time in forest and coffee agroforestry systems in Sumberjaya, West Lampung. Forest Ecol Manage 224: 45-57.

Hanel L. 2001. Succession of soil nematodes in pine forests on coal-mining sands near Cottbus, Germany. Appl Soil Ecol 16: 23-34.

Hashimoto Y. 2010. Identification Guide to Ant Genera of Borneo.http://homepage.mac.co/aenictus/ AntsofBorneo.htm. downloads: December 25. 2010.

Hedde M, P Lavelle, R Joffre, JJ Jiménez and T Decaëns. 2005. Specific functional signature in soil macroinvertebrate biostructures. Func Ecol 19: 785-793.

Henrot J and L Brussard. 1997. Abundance, casting activity, and cast quality of earthworms in an acid Ultisol under alley-cropping in the humid tropics. Appl Soil Ecol 6: 169-179.

Hooper DU, FS Chapin III, JJ Ewel, A Hector, P Inchausti, S Lavorel, JH Lawton, DM Lodge, M Loreau, S Naeem, B Schmid, H Setälä, AJ Symstad, J Vandermeer and DA Wardle. 2005. Effects of biodiversity on ecosystem functioning: a consensus of current knowledge. Ecol Monog 75: 3-35. 
Hubbell SP. 2001. The unified neutral theory of biodiversity and biogeography. Princeton University Press, New Jersey, 375p.

James SM. 2000. An illustrated key to the earthworms of the Samaon Archipelago (Oligochaeta: Glossoscolecidae. Moniligastridae). Technical Report No. 49. Originally submitted in 2000.

Jones CG, JH Lawton and M Shack. 1994. Organisms as ecosystem engineers. Oikos 69: 373-386.

Jones DT, FX Susilo, DE Bignell, S Hardiwinoto, AN Gillison and PEggleton. 2003. Termite assemblage collapse along a land-use intensification gradient in lowland central Sumatra, Indonesia. J Appl Ecol 40: 380-391.

Kilowasid LOH, Tati-Subahar S Syamsudin, Endah Sulistiawaty and FX Susilo. 2010. Komposisi dan kelimpahan fauna tanah sebagai perekayasa ekosistem di kebun kakao rakyat Kabupaten Konawe Selatan. Sulawesi Tenggara. In: (eds)Prosiding Seminar Nasional Keragaman Hayati Tanah-1. Bandar Lampung. 29-30 Juni 2010, pp. 12-28.

Lavelle P. 1996. Diversity of soil fauna and ecosystem function. Biol Int 33: 4-16.

Mathieu J, JP Rossi, P Mora, P Lavelle, PFS Martins, C Rouland and M Grimaldi. 2005. Recovery of soil macrofauna communities after forest clearance in eastern Amazonia, Brazil. Conserv Biol 19(5): 1598-1605.

Mertl AL, FAJ Traniello, KR Wilkie and R Constantino. 2012. Associations of two ecologally significant social insect taxa in the litter of an Amazonian Rainforest: Is there a relationship between ant and termite species richness?. Psyche 2012: 1-12. doi:10.1155/2012/312054.

Miranda CS, A Vasconcellos and AG. Bandeira. 2004. Termites in sugarcane in Northeast Brazil: Ecological aspects and pest status. Neotrop Entomol 33 (2): 237-241.

Moco MKS, EF da Gama-Rodrigues, AC da GamaRodrigues, RCR Machado and VC Baligar. 2009. Soil and litter fauna of cacao agroforestry systems in Bahia, Brazil. Agroforest Syst 76: 127-138.

Moco MKS, EF Gama-Rodrigues, AC Gama-Rodrigues, RCR Machado and VC Baligar. 2010. Relationships between invertebrate communities, litter quality and soil attributes under different cacao agroforestry systems in the south of Bahia, Brazil. Appl Soil Ecol 46: 347-354.

Nath S, and PS Chaudhuri. 2010. Human-induced biological invasions in rubber (Hevea brasiliensis) plantations of Tripura (India) - Pontoscolex corethrurus as a case study. Asian J Exp Biol Sci 1 (2): 360-369.

Nunes DH, A Pasini, NP Benito and GG Brown. 2006. Earthworm diversity in four land use systems in the region of Jaguapitã, Paraná State, Brazil. Caribbean J Sci 42: 331-338.
Norgrove L, C Csuzdi, F Forzi, M Canet and J Gounes. 2009. Shift in soil community structure in shaded cacao agroforests and consequences for ecosystem function in Central Africa. Trop Ecol 50 (1): 71-78.

Osler GHR and M Sommerkorn. 2007. Toward a complete soil $\mathrm{C}$ and $\mathrm{N}$ cycle: Incorporating the soil fauna. Ecology 88: 1611-1621.

Parker SS. 2010. Buried treasure: soil biodiversity and conservation. Biodivers Conserv 19: 3743-3756.

Rosenzweig ML. 1999. Species diversity. In: J McGlade (eds). Advanced Ecological Theory Principles and Applications. Blackwell Science. London, pp. 249-281.

Sabrina, DT, MM Hanafi, AA Nor Azwady and TMM Mahmud. 2009. Earthworm populations and cast properties in the soils of oil palm plantations. Malaysian J Soil Sci 13: 29-42.

Shahabuddin. 2010. Diversity and community structure of dung beetles (Coleoptera: Scarabaeidae) across a habitat disturbance gradient in Lore Lindu National Park, Central Sulawesi. Biodiversitas 11: 29-33.

Silva RR and CRF Brandao. 2010. Morphological patterns and community organization in leaf-litter ant assemblages. Ecol Monog 80: 107-124.

Soil Survey Staff. 2010. Keys to Soil Taxonomy. Eleventh Editions. United Stated Department of Agriculture. Natural Resources Conservation Service

Straube D, EA Johnson, D Parkinson, S Scheu and N Eisenhauer. 2009. Nonlinearity of effects of invasive ecosystem engineers on abiotic soil properties and soil biota. Oikos 118 (6): 885-896. doi: 10.1111/j.16000706.2009.17405.x.

Susilo FX, AM Neutel, M van Noordwijk, K Hairiah, G Brown and MJ Swift. 2004. Soil biodiversity and food webs. In: van Noordwijk M, Cadish G, Ong CK (eds) Below-ground interactions in tropical agroecosystems: concept and models with multiple plant components. CABI Publishing, pp. 285-307.

Swift MJ, AMN Izac and M van Noordwijk. 2004. Biodiversity and ecosystem services in agricultural landscapes-are we asking the right questions? Agric Ecosyst Environ 104: 113-134.

Tho YP. 1992. Termites of Peninsular Malaysia. Forest Research Institute Malaysia, Kepong. Kualalumpur. $224 \mathrm{p}$.

Tillberg CV, DA Holway, EG LeBrun and AV Suarez. 2007. Trophic ecology of invasive Argentine ants in their native and introduced ranges. PNAS 104: 20856-20861.

Turner EC and WA Foster. 2009. The impact of forest conversion to oil palm on arthropod abundance and biomass in Sabah, Malaysia. J Trop Ecol 25: 23-30.

Virolainen KM, T Suomi, J. Suhonen and M. Kuitunen. 1998. Conservation of vascular plants in single large and several small mires: species richness, rarity and taxonomic diversity. J Appl Ecol 35: 700-707.

Wielgoss A, T Tscharntke, D Buchori, B Fiala and Y Clough. 2010. Temperature and a dominant dolichoderine ant species affect and diversity in Indonesia cacao plantations. Agric Ecosyst Environ 135: 253-259. 